\title{
Cerebrum-cervical arterial dissection in adults during sports and recreation
}

\author{
Dissecção arterial cérebro-cervical em adultos durante prática de esportes e recreação
}

Yara Dadalti Fragoso', Tarso Adoni², Lazaro Luiz Faria do Amaral', Flavio Tulio Braga 4 , Joseph Bruno

Bidin Brooks ${ }^{1}$, Christiane Siqueira Campos ${ }^{3}$, Elizabeth Regina Comini-Frota ${ }^{5}$, Nelson Paes Fortes Diniz

Ferreira ${ }^{4}$, Luciano Marcus Tirotti Giacon6, Sidney Gomes ${ }^{3,6}$, Marcus Vinicius Magno Goncalves7, Pedro Silva

Correa Magalhaes ${ }^{8}$, Andre Palma da Cunha Matta ${ }^{9}$, Francisco Tomaz Meneses de Oliveira ${ }^{3}$, Joao Felipe de

Oliveira ${ }^{10}$, Marco Antonio Pierucettti ${ }^{6}$, Samira Luisa dos Apostolos Pereira ${ }^{11}$, Maciel Eduardo Pontes ${ }^{12}$, Fabio

Siquineli10, Carlos Bernardo Tauil12, Guilherme Navarro Troaini ${ }^{1}$

\begin{abstract}
Dissection of cervical arteries constitutes a medical emergency. Although relatively rarely, activities classified as sports and recreation may be a cause of arterial dissection independently of neck or head trauma. The purpose of the present paper was to present a series of cases of cerebrum-cervical arterial dissection in individuals during or soon after the practice of these sports activities. Methods: Retrospective data on patients with arterial dissection related to sports and recreation. Results: Forty-one cases were identified. The most frequently affected vessel was the vertebral artery. A large variety of activities had a temporal relationship to arterial dissection, and jogging was the most frequent of these. This is the largest case series in the literature. Conclusion: Arterial dissection may be a complication from practicing sports.
\end{abstract}

Keywords: dissection, carotid artery, vertebral arterial, stroke.

\section{RESUMO}

A dissecção das artérias cervicais é uma emergência médica. Embora de forma relativamente rara, certas atividades descritas como esportes e recreação podem ser a causa de dissecção arterial independentemente de trauma de crânio ou cervical. O propósito do presente estudo é apresentar uma série de casos de dissecção de artérias cérebro-cervicais em indivíduos durante ou logo após a prática destas atividades desportivas. Métodos: Dados retrospectivos de pacientes com dissecção arterial relacionada à prática de esportes e recreação. Resultados: Quarenta e um casos foram identificados. A artéria mais frequentemente afetada foi a vertebral. Uma grande variedade de atividades teve relação temporal com a dissecção arterial, sendo a corrida a mais frequente delas. Esta é a maior série de casos da literatura. Conclusão: Dissecção arterial pode ser uma complicação da prática de esportes.

Palavras-chave: dissecção, artéria carótida, artéria vertebral, acidente vascular cerebral.

Dissection of cervical arteries can lead to severe sequelae and constitutes a medical emergency. Among the causes of this dissection, trauma to the neck rates high in importance.
When trauma is extensive, such as in motor vehicle accidents, the risk of dissection is clear and most doctors attending these patients at the scene or at the time of hospital admission will

\footnotetext{
'Universidade Metropolitana de Santos, Santos SP, Brazil;

${ }^{2}$ Hospital Sírio-Libanês de São Paulo, Sao Paulo SP, Brazil;

${ }^{3}$ Hospital Beneficência Portuguesa de São Paulo, Sao Paulo SP, Brazil;

${ }^{4}$ Hospital do Coracão, Sao Paulo SP, Brazil;

5Universidade Federal de Minas Gerais, Belo Horizonte MG, Brazil;

${ }^{6}$ Hospital Paulistano, Sao Paulo SP, Brazil;

${ }^{7}$ Centro Hospitalar UNIMED, Joiville SC, Brazil;

${ }^{8}$ Clinica Neurológica Joinville, Joinville SC, Brazil;

`Universidade Federal Fluminense, Niteroi RJ, Brazil;

${ }^{10}$ Universidade Regional de Blumenau, Blumenau SC, Brazil;

${ }^{11}$ Universidade de São Paulo, Sao Paulo SP, Brazil;

${ }^{12}$ Hospital de Base de Brasília, Brasilia DF, Brazil.
}

Correspondence: Yara Dadalti Fragoso; Departamento de Neurologia, Faculdade de Medicina - UNIMES; Rua da Constituicao, 374 ; 11015 -470 Santos SP, Brasil; E-mail:yara@bsnet.com.br

Conflict of interest: There is no conflict of interest to declare.

Received 16 December 2014; Received in final form 17 July 2015; Accepted 06 August 2015. 
consider this possibility ${ }^{1}$. However, when trauma occurs during sports or recreation, it may be more difficult to recognize the clinical manifestations of the arterial injury. In addition, the trauma may be minimal and not be perceived as such, thus making the diagnosis more difficult. The possible influence of these sport-related traumatic events may be further underestimated if longer intervals between vessel dissection and ischemia occur.

The literature on the subject is rich in isolated cases or small case series, showing a variety of sports that can be related to cervical arterial dissection. Soccer ${ }^{2}$, diving ${ }^{3,4}$, wakeboarding $^{5}$, golf $f^{6}$, treadmill running ${ }^{7}$, horse riding 8 , snowboarding 9 , physical fitness testing $^{10}$, triathlon ${ }^{11}$, heavy weight-lifting ${ }^{12,13}$, volleyball ${ }^{14}$, basketball ${ }^{15}$, skating ${ }^{16}$, gymnastics ${ }^{17}$, tennis ${ }^{18}$ and martial arts ${ }^{19,20,21,22}$ are examples of these cases found in the literature. Even virtual sports, practiced using the Wii device, have been correlated with arterial dissections of the neck ${ }^{23}$. There are few case series on sport-related arterial dissection of the cerebrum-cervical system, and the largest and most recent series reports 10 cases $^{24}$.

The aim of the present study was to report on a large series of patients with cerebrum-cervical arterial dissection during a variety of sport or recreational activities.

\section{METHOD}

Neurologists at different units in Brazil were invited (personally and via e-mail) to forward cases of arterial dissection of the neck that had occurred during or immediately after sport or recreational activities. Cases involving motor vehicle accidents were not included, even if they were considered to be a sportive activity (e.g. motocross).

Retrospective data were collected from the medical records of patients who had already signed a consent statement at the time of hospital admission. The present study was approved by the Ethics Committee (Institutional Review Board) of Universidade Metropolitana de Santos, under the number CAAE 37485714.7.0000.5509. Whenever necessary, additional approval was obtained from other institutions.

Analyses of the results were done in an essentially descriptive manner, and no other statistical methods were used.

\section{RESULTS}

Forty-one cases of sport-related arterial dissections were identified. A summary of all the cases is presented in Table. A similar same numbers of men and women were affected (21 men and 20 women) and their average age at the time of the dissection was 39.4 years (range: 18 to 68 years of age). Four individuals presented high blood pressure before arterial dissection and one of them had had a previous stroke. These patients were undergoing treatment and were considered fit for physical activity. None of the subjects was a smoker or was using performance-enhancing drugs. None of them had head trauma at the time of the dissection, and only two of the individuals had been subjected to potential neck trauma (direct pressure on the neck in jujitsu practice). Jogging was found to be the most frequent activity preceding arterial dissection, affecting 18 individuals. Six patients correlated their dissection with doing brisk walks. In fact, jogging and brisk walks may not have been the cause of the dissection, but the temporal relationship between the events led us to include these cases in the cohort.

Four patients presented dissection during martial arts practice, three during swimming, two during muscle-building exercises, two during Pilates practice, and one each during scuba diving, soccer, bungee-jumping, gymnastics, belly dancing and tennis. The neurological symptoms occurred up to five days after the sports events.

The vertebral arteries were the most frequently affected vessels (11 cases on the left and 10 on the right side). Dissection of the following carotid arteries was observed: internal (eleven cases), external (four cases) and common (five cases). A list of the arteries affected in each case, along with the clinical manifestations according to the Bamford classification $^{25}$, is presented in Table.

In nine cases, the dissection occurred in the intracranial segment of the arteries, while in 30 cases it affected the extracranial segment. In two cases, both intra- and extracranial segments were affected. There were three cases of embolism and complete obstruction of cerebral arteries, one of which resulted in death (dissection of both carotid arteries and occlusion of the middle cerebral artery). This was a 40-year-old female who was jogging. One patient (male aged 22 years) who presented left vertebral artery dissection during martial arts practice progressed to brain death. One patient (male aged 42 years) who presented dissection of the left common carotid artery while swimming also remains in a vegetative coma with right hemiplegia. Twenty-one patients $(52.5 \%)$ present neurological sequelae of the arterial dissection.

Regarding the National Institutes of Health Stroke Scale $(\mathrm{NIHSS})^{26}$, the patients scored between zero and 24 points (this last being the case of death). There were five cases with NIHSS scores of 16 points or above. On average, the NIHSS score was $8.6 \pm 7.0$ points. At the time when the patients were released from hospital, the score on the Rankin modified scale $^{27,28}$ ranged from zero to five points (average $1.7 \pm 1.3$ ).

A few images from examinations on these patients are shown in Figure. Ischemic lesions of different areas of the brain, brainstem and cerebellum were common, and angiography confirmed and located the arterial dissection.

The treatment consisted of full anticoagulation for $35 \mathrm{pa}-$ tients, two of whom also received a stent. There was one case of stent use without anticoagulation and three cases of treatment with anti-platelet drugs. Four patients underwent craniotomy due to the extensive brain lesion and edema. Details of these cases are also shown in Table. 


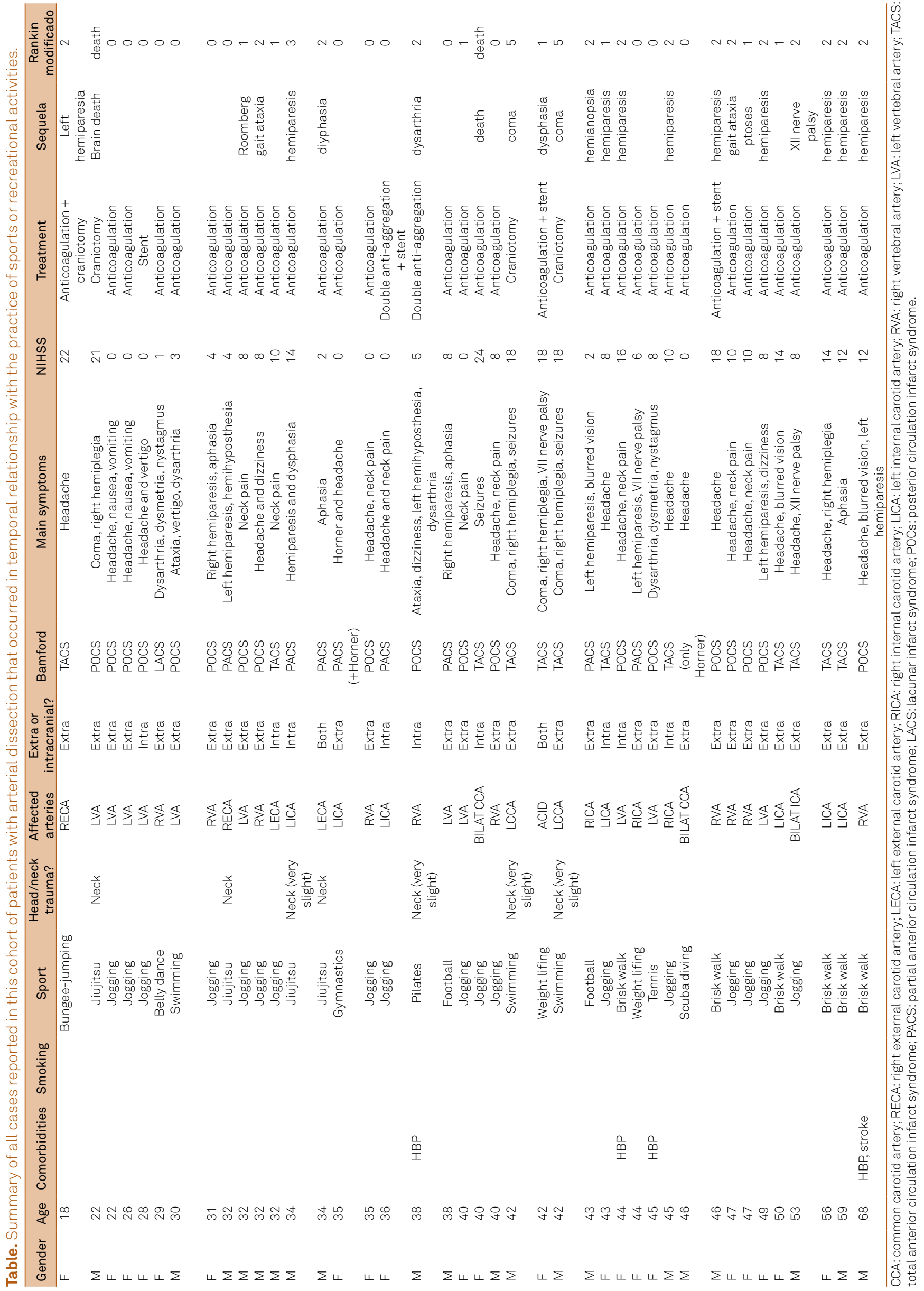



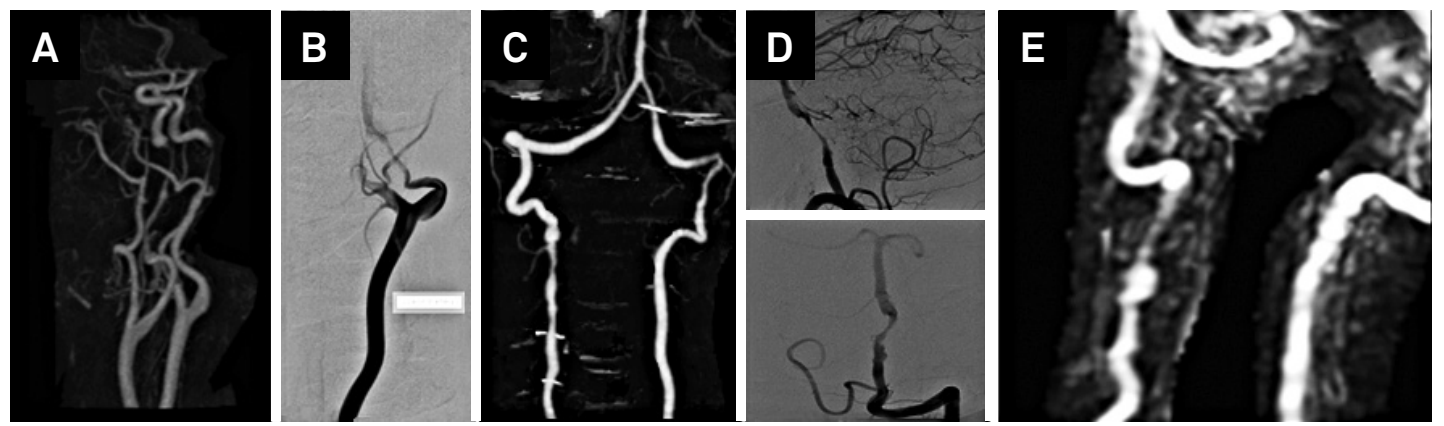

Figure. Images of angiography in cerebrum-cervical arterial dissection. A: bilateral internal carotid arterial dissection; B: left internal carotid artery; C and D: two cases of dissection of the left vertebral artery; E: right vertebral artery.

\section{DISCUSSION}

Regular practicing of sports and recreational activities is an important part of a healthy life. Acute and severe accidents or injuries during sports occur infrequently and should never be a deterrent to physical activity. However, it is important to acknowledge that arterial dissection may be a complication from practicing sports. Cervical trauma has been described as an important determinant of cervical arterial dissection, although it is not the only outcome predictor in these patients ${ }^{29}$. Recognition of this medical emergency is essential and the literature on the subject is, at present, very poor. A comprehensive review of the literature showed that, so far, only isolated cases or small series have been publish $\mathrm{ed}^{23,3,4,5,6,7,8,9,10,11,12,13,14,15,16,17,18,19,20,21,22,23,24}$. Of all the sports potentially related to cerebrum-cervical arterial dissection, scuba diving ${ }^{25}$ and martial arts $^{20,21,22}$ are those that are most often mentioned in the literature. This was not the experience of the authors of the present paper, who found that jogging was the main activity temporally related to arterial dissection among our patients.

The study presents limitations, as it is a pooled cohort from a large number of Neurology Units in Brazil. This was not a systematic collection of cases and no conclusions can be drawn regarding prevalence of arterial dissection, mechanisms for this arterial damage or even whether the activity was indeed the sole cause of vessel dissection. On the other hand, the present study brought in a large series of cases with a variety of sports potentially related to arterial dissection, including some not mentioned before. Failure to suspect a dissection in the context of a sport-related injury and therefore to proceed with the correct therapy can lead to permanent neurological deficits.

\section{References}

1. Nedeltchev K, Baumgartner RW. Traumatic cervical artery dissection. Front Neurol Neurosci. 2005;20:54-63. doi:10.1159/000088149

2. Tașcılar N, Ozen B, Açıkgöz M, Ekem S, Acıman E, Gül S. Traumatic internal carotid artery dissection associated with playing soccer: a case report. Ulus Travma Acil Cerrahi Derg. 2011;17(4):371-3. doi:10.5505/tjtes.2011.60134

3. Furtner M, Werner P, Felber S, Schmidauer C. Bilateral carotid artery dissection caused by springboard diving. Clin J Sport Med. 2006;16(1):76-8. doi:10.1097/01.jsm.0000173267.84112.a0

4. Hafner F, Gary T, Harald F, Pilger E, Groell R, Brodmann M. Dissection of the internal carotid artery after SCUBA-diving: a case report and review of the literature. Neurologist. 2011;17(2):79-82. doi:10.1097/NRL.0b013e3181e6a416

5. Fridley J, Mackey J, Hampton C, Duckworth E, Bershad E. Internal carotid artery dissection and stroke associated with wakeboarding. J Clin Neurosci. 2011;18(9):1258-60. doi:10.1016/j.jocn.2011.02.013

6. Maroon JC, Gardner P, Abla AA, El-Kadi H, Bost J. "Golfer's stroke”: golf-induced stroke from vertebral artery dissection. Surg Neurol. 2007;67(2):163-8. doi:10.1016/j.surneu.2006.03.045

7. Macdonald DJ, McKillop EC. Carotid artery dissection after treadmill running. Br J Sports Med2006;40(4):e10. doi:10.1136/bjsm.2005.020586

8. Fletcher J, Davies PT, Lewis T, Campbell MJ. Traumatic carotid and vertebral artery dissection in a professional jockey: a cautionary tale. Br J Sports Med. 1995;29(2):143-4. doi:10.1136/bjsm.29.2.143
9. Kalantzis G, Georgalas I, Chang BY, Ong C, El-Hindy N. An unusual case of traumatic internal carotid artery dissection during snowboarding. J Sports Sci Med. 2014;13(2):451-3.

10. Statler JD, Ronsivalle JA, Depper MH, Rao KC. Bilateral carotid artery dissection during the Army physical fitness test. Mil Med. 1998;163(12):857-60.

11. Sparing R, Hesse MD, Schiefer J. [Traumatic internal carotid artery dissection associated with triathlon: a rare differential diagnosis]. Sportverletz Sportschaden. 2005;19(4):211-3. German. doi:10.1055/s-2005-858475

12. Berrouschot J, Bormann A, Routsi D, Stoll A. [Sports-related carotid artery dissection]. Fortschr Neurol Psychiatr. 2009;77(9):528-31. German. doi:10.1055/s-0028-1109699

13. Low A, Dovey J, Ash-Miles J. Vertebral artery dissection in weightlifter with performance enhancing drug use. BMJ Case Rep. 2011;2011.

14. Slankamenac P, Jesic A, Avramov P, Zivanovic Z, Covic S, Till V. Multiple cervical artery dissection in a volleyball player. Arch Neurol. 2010;67(8):1024. doi:10.1001/archneurol.2010.160

15. De Giorgio F, Vetrugno G, De Mercurio D, Pascali VL, Rainio J, Carbone A et al. 1. Dissection of the vertebral artery during a basketball game: a case report. Med Sci Law. 2004;44(1):80-6. doi:10.1258/rsmmsl.44.1.80

16. Karnik R, Rothmund T, Bonner G, Valentin A, Reuther G. Inline skating as a possible cause of consecutive bilateral vertebral artery dissection. Acta Neurol Scand. 2000;101(1):70-1. doi:10.1034/j.1600-0404.2000.00010.x 
17. De Broucker T, Amazan C, Forys E, Piquet V. [Dissection of a vertebral artery during gymnastics]. Presse Med. 1990;19(4):176.

18. Roualdes G, Lartigue C, Boudigue MD, Van der Marcq P, Drouineau J, Desplat A et al. [Dissection of the extracranial vertebral artery after a tennis match]. Presse Med. 1985;14(41):2108. French.

19. Lannuzel A, Moulin T, Amsallem D, Galmiche J, Rumbach L. Vertebral-artery dissection following a judo session: a case report. Neuropediatrics. 1994;25(2):106-8. doi:10.1055/s-2008-1071595

20. Pary LF, Rodnitzky RL. Traumatic internal carotid artery dissection associated with taekwondo. Neurology. 2003;60(8):1392-1393. doi:10.1212/01.WNL.0000055924.12065.A0

21. Slowey M, Maw G, Furyk J. Case report on vertebral artery dissection in mixed martial arts. Emerg Med Australas. 2012;24(2):203-6. doi:10.1111/j.1742-6723.2011.01496.x

22. Suzuki R, Osaki M, Endo K, Amano T, Minematsu K, Toyoda K. Common carotid artery dissection caused by a frontal thrust in Kendo (Japanese swordsmanship). Circulation 2012;125(17):e617-9. doi:10.1161/CIRCULATIONAHA.111.066472

23. Faivre A, Chapon F, Combaz X, Nicoli F. Internal carotid artery dissection occurring during intensive practice with Wii video sports games. Neurology. 2009;73(15):1242-3. doi:10.1212/WNL.0b013e3181bc0172
24. Alexandrino GM, Damásio J, Canhão P, Geraldes R, Melo TP, Correia C et al. Stroke in sports: a case series. J Neurol. 2014;261(8):1570-4. doi:10.1007/s00415-014-7383-y

25. Brajkovic S, Riboldi G, Govoni A, Corti S, Bresolin N, Comi GP. Growing evidence about the relationship between vessel dissection and scuba diving. Case Rep Neurol. 2013;5(3):155-61. doi:10.1159/000354979

26. Wilson JT, Hareendran A, Grant M, Baird T, Schulz UG, Muir KW et al. Improving the assessment of outcomes in stroke: use of a structured interview to assign grades on the modified Rankin Scale. Stroke. 2002;33(9):2243-6. doi:10.1161/01.STR.0000027437.22450.BD

27. Bamford J, Sandercock P, Dennis M, Burn J, Warlow C. Classification and natural history of clinically identifiable subtypes of cerebral infarction. Lancet. 1991;337(8756):1521-6. doi:10.1016/0140-6736(91)93206-0

28. Brott T, Adams HP Jr, Olinger CP, Marler JR, Barsan WG, Biller J et al. Measurements of acute cerebral infarction: a clinical examination scale. Stroke. 1989;20(7):864-70. doi:10.1161/01.STR.20.7.864

29. Engelter ST, Grond-Ginsbach C, Metso TM, Metso AJ, Kloss M, Debette S et al.; Cervical Artery Dissection and Ischemic Stroke Patients Study Group. Cervical artery dissection: trauma and other potential mechanical trigger events. Neurology. 2013;80(21):1950-7. doi:10.1212/WNL.0b013e318293e2eb 


\section{Erratum}

Arquivos de Neuro-Psiquiatria. 2016;74(4):275-279. doi:10.1590/0004-282X20150150

The original Table with report of individual cases in the on line version of the article "Cerebrum-cervical arterial dissection in adults during sports and recreation" contained some mistakes. We have now provided the corrected version of the Table, removing the column with the Bamford classification, as per decision of all authors of the paper. 


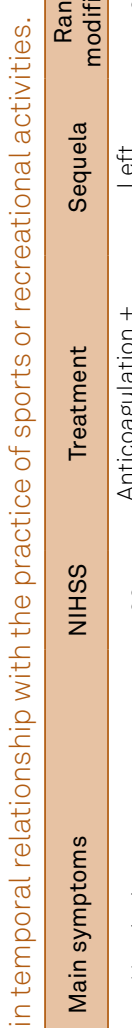

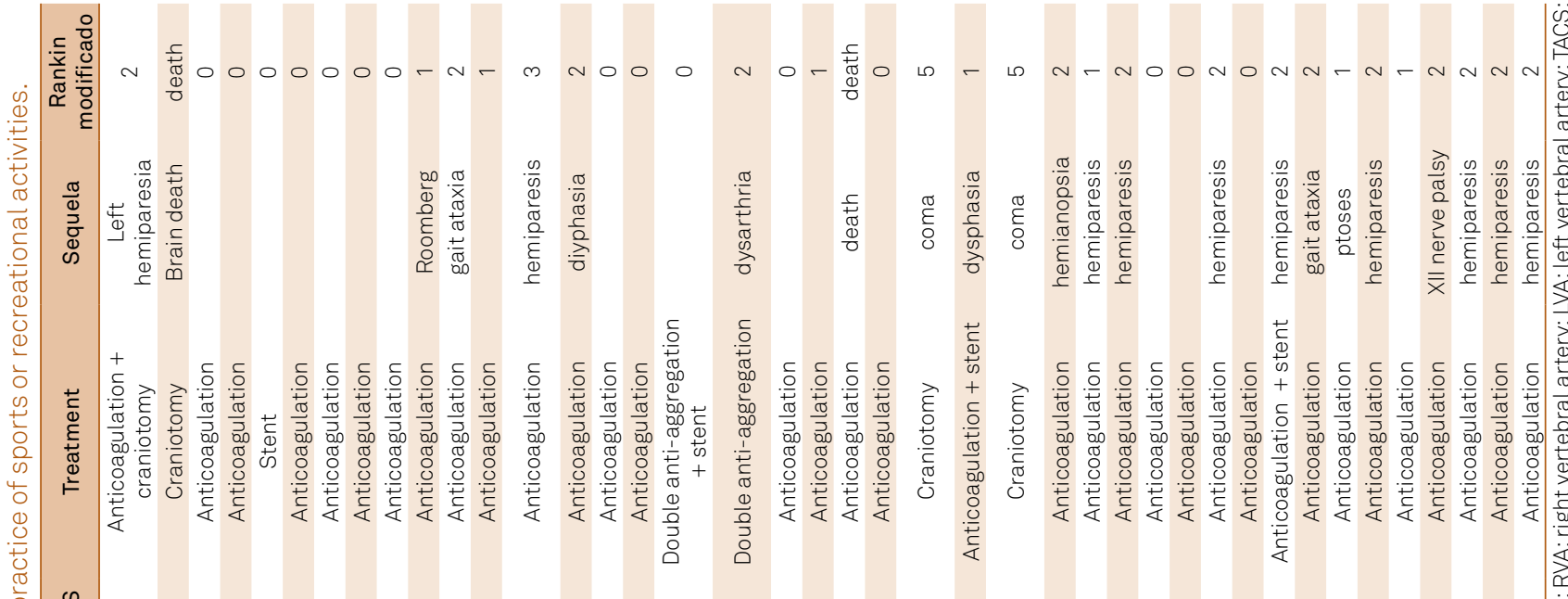

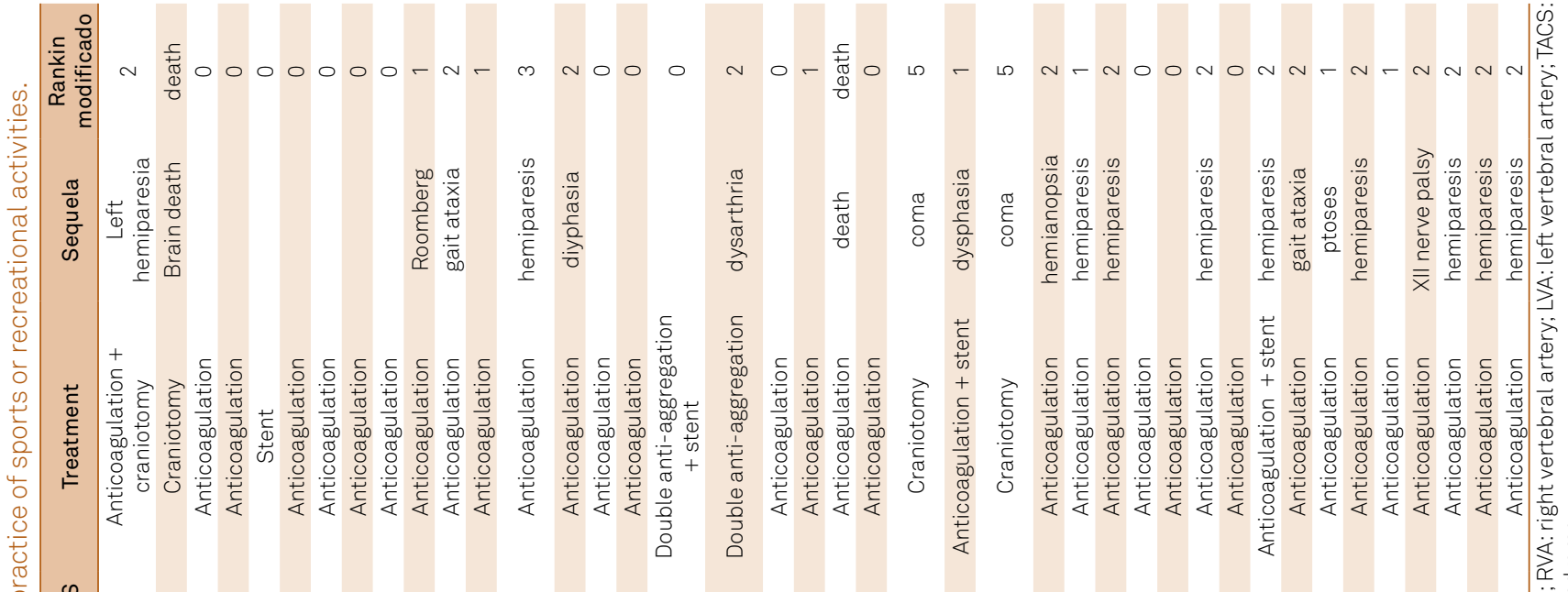

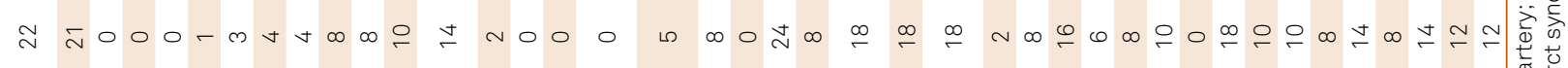

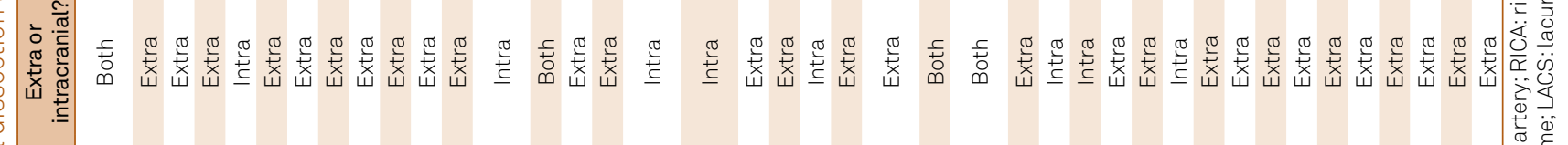

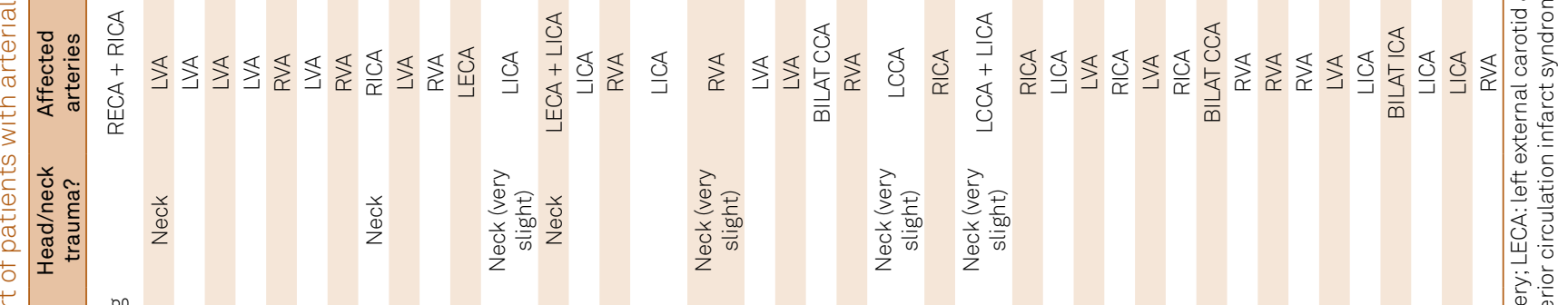

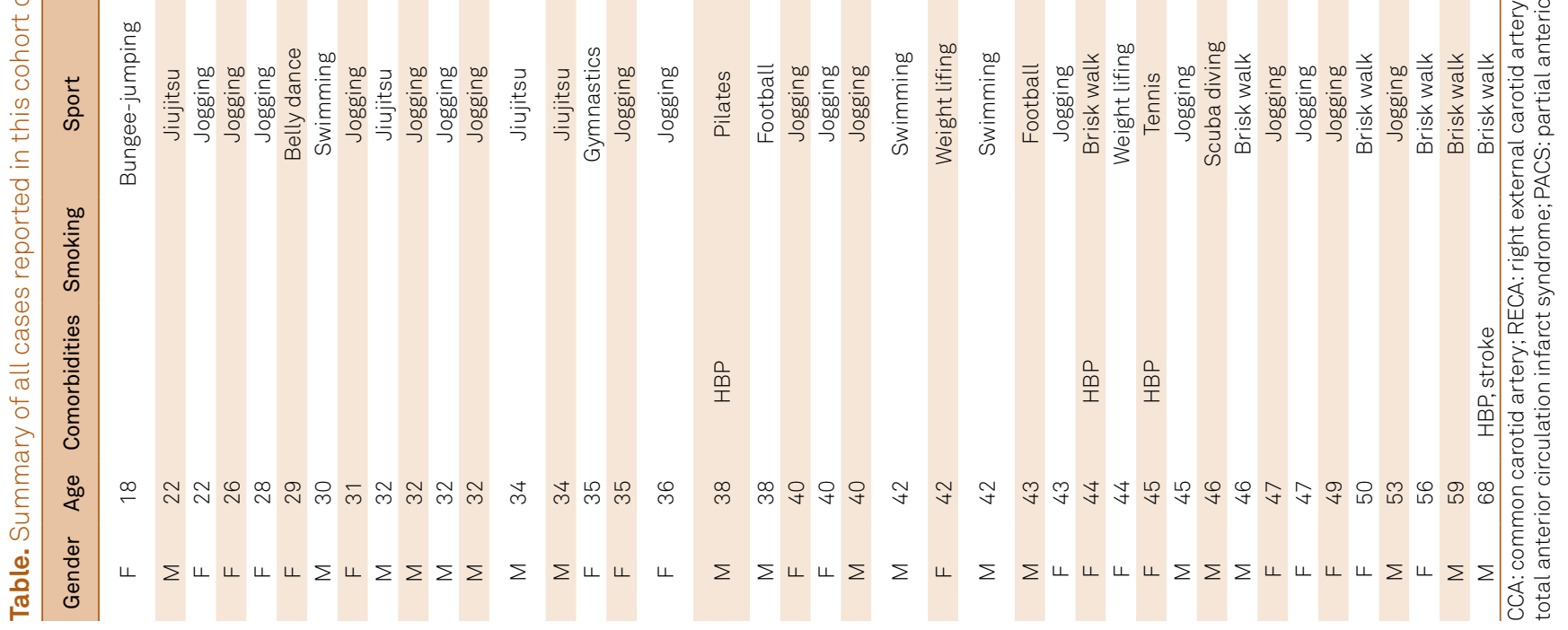

